\title{
Good Governance and Building a Civil Service in a Fragile State: The Case of Timor Leste
}

\author{
*Shaun Goldfinch ${ }^{1}$, Karl DeRouen ${ }^{2}$ \\ ${ }^{1}$ Nottingham University Business School \\ 2University of Alabama \\ *shaun.goldfinch@nottingham.ac.uk
}

\begin{abstract}
Newly independent Timor Leste provides a unique case study of the difficulties of developing a civil service in a fragile state. We show the UN and other bodies have attempted to develop a reasonably traditional Weberian legal/rational type civil service, but that many difficulties remain.
\end{abstract}

Keywords: Civil service reform, East Timor, good governance, post-conflict, state building, Timor Leste

\section{Introduction}

On 29 October 1999 Indonesian forces abandoned the former Portuguese colony of East Timor after 24 years of remarkably brutal and genocidal occupation. The United Nations Transitional Administration in East Timor (UNTEAT) was established on 25 October 1999 to develop East Timor towards independence. East Timor became a UN colony, with governance and judicial power assumed by the United Nations authority, and progressively shared with Timorese elites until independence in 2002, when its official name became Timor Leste. This mission has been superseded by three other UN missions, providing for some confusing acronyms. The previous United Nations Mission in East Timor (UNAMET) which ran from June - October 1999 was a political mission to establish the referendum that established Timorese independence, and largely fled during the 1999 troubles. Its successor, UNTEAT, above, was superseded by the United Nations Mission of Support in East Timor (UNMISET), which was a peace keeping mission to provide assistance to the newly independent Timor. This ran from May 2002 - May 2005. This was superseded by the 'political mission' the United Nations Office in Timor-Leste (UNOTIL) which ran from May 2005-August 2006 to provide support for the development of governance and democracy. This in turn was superseded by another peace keeping/police mission United Nations Integrated Mission in Timor-Leste (UNMIT) which was introduced in response to further unrest in 2006 and which is in existence to this day, but with their mandate expected to finish at the end of 2012 . Drawing on interviews with key participants, and a survey of primary and secondary literature, this study seeks to understand the difficulties government and international agencies face developing a civil service in a post-conflict environment.

The UN returned to a country in 1999 that had been largely destroyed by Indonesian troops and their client militias after the population overwhelmingly voted for independence. The capital Dili was leveled. Infrastructure was in ruins and the basis structures and personnel of a state were absent. Records were removed or destroyed. Several thousand Indonesian officials and school teachers - estimated at around 7000 - and some Timorese that considered themselves irredeemably compromised, fled. Others were forcibly removed by the Indonesians. The Timorese public service that did remain was often a ghost workforce, and/or one with little training, experience or capacity, which the Indonesians had paid partly to tie them to the regime, but expected little work in return. As a Timorese official noted the public servants, the skilled people, were Indonesians and they left. The Timorese, they had a job but they didn't have the skill. They didn't basically do anything. They didn't learn. My relatives told us very frequently, we had a job; we would go and like mark our presence. We got our payment and then if we show up, we show up. If you don't show up, you don't show up. With Dili a ruin, the new UN regime set itself up in shipping containers, and tents sometimes pitched in 'tent city' in the Plenary hall of Parliament. Essentially nothing remained from the occupational state. As a UN official noted the Ministry of Education [was] the third desk from the left. There was indeed one desk and two chairs. And they showed a little folder with about twenty sheets of paper in it. That was it. So that was where it all began.

\section{Building a Civil Service}

Recruitment of public servants began in earnest, but even Timorese from the Diaspora were reluctant to return for the minuscule salaries paid in one of the poorest countries in the world 'particularly when 
people realized that the starting salary for a public servant was seventy dollars [a month]', as one former UN official noted. Entry level positions at least could be 'trained-up', and some leadership positions could be filled by returning expats and/or resistance leaders. However, the lack of suitable staff was particularly bad for mid-level positions. There was also some reliance on re-hiring former employees of the Indonesian regime, particularly in the case of the Police. The notion of loyalty to the new regime was highly complex, given the morass of (dis)loyalties, accommodation and dissemblance in an occupational regime. For a resistance that saw itself as defeating a large Indonesian invasion, notions of a neutral public service rather than one that served the government of the day was a difficult one. As a UN official noted we were pursuing the concept of a neutral, impartial, public service. Not all members of the political elite, the Timorese political elite, agreed with that and there would be battles over this. And if you were to find people who actually had some level of experience, they were all being former, you know, officials during the Indonesian period. Of course many of them in fact were also politically acceptable because many had been [secretly] working for the resistance. Leaders at the political level in the new government after 2002 had virtually no experience in government, beyond the short time in 1975 before the Indonesian invasion. The problem with public servants with a background in the resistance, but with mixed skills, was that it was difficult to retire them or force them into training. Years of brutal occupation meant many locals suffered psycho-social problems. Strong ties, links with newly ascendant elites and former resistance leaders could act as patronage to access government jobs, with patronage important from the highly divided resistance movement, members of which sought to promote those they saw as loyal. Notions of appointment on merit did not sit well in a culture where it was expected that family, clans and language groups would be favored in appointment, and where in a highly underdeveloped country, government jobs might be the only ones available. These problems were compounded by a lack of training and education available.

Some of the Timorese expats that did return were attracted to positions in international organizations, such as the UN, which paid considerably higher salaries than could be paid by the government. Some, while ethnically Timorese, had foreign passports, and Australian and/or Portuguese educations, and were known by the locals as 'Foreign Timorese'; Timor-Malai. These foreign educations and passports also allowed movement in-and-out of Timor, and some stayed only a short time before returning to Australia and Portugal, largely because of the low salaries. Consultants hired on short-term contracts paying international rates to carry out public sector tasks, sometimes of Timorese background, faced resentment from local and considerably less well-paid local Timorese public servants, but also faced some uncertainty of tenure, with jobs potentially changing with changes of government. Returning expats: some from Portugal or its former colonies who spoke Portuguese - including the returning political leadership: some from Australia with Australian educations and strong English: faced a large number of language groups and divided loyalties of a population that had remained through the occupation. This provided for a complex and difficult mix. Generational differences between the older population that spoke some Portuguese, and those that had grown up and been educated in Indonesian Bahasa during the occupation were compounded by other issues, such as those born before 1999 were eligible to apply for a Portuguese passport and so work in the EU. Despite 14 years of development, capacity in terms of the public bureaucracy still remains low, as does means of developing this capacity. Even as late as 2010, there was a strong lack of advanced academic training for public servants available in Timor Leste. For example, the Portuguese university (one of two in Timor Leste) in Dili did not teach public administration as of 2010. However, courses of various types were being offered by differing agencies, as noted below. Even so, basic skills in literacy and numeracy are lacking. As a UN official noted The World Bank, they also tested all the staff of the Ministry of Finance. They're supposed to deal with all the figures every day. And their conclusion is the average is grade three of primary school. Some are below grade three. That is the level If you want to teach, then you find this suddenly after one month, two months, [they are] indeed illiterate. What can you do? So most of the experts [are] facing this kind of culture shock because the level is so low. They wonder what we can teach. It's much easier for him or her to do the work rather than teach because basic knowledge is so [low].

So the government is now recruiting... but they are still in the junior level. In the middle level and others, [is] the large chunk of the people who didn't not get any education, but because of political reasons, government cannot kick out all these kinds of people. There is no pension scheme. There is no shortage of applicants for jobs. For a country that lacks any major industry outside oil and subsidence agriculture and with virtually no manufacturing and limited service industries, the government remains the key source of employment. For each position they may be a thousand applications, albeit with well over half woefully under-qualified for the position. In any event, records are such that it is still not entirely clear 
how many are employed, or if some employed are simply ghost workers; although to collect pay they physically have to be present at least so may have a corporeal form. One senior official noted estimates ranged 'from twenty-three to twenty-eight thousand [although] ...it's probably twenty-four thousand civil servants.' A senior UN official noted the World Bank and other international advisors said [the] appropriate number or maximum number of the civil servants should be twelve thousand. That's why socalled regular permanent civil servant is about twelve thousand still, but in fact we have almost same number of about twelve thousand who are temporary staff. We call it temporary because the ceiling is twelve thousand. But indeed they are the civil servants. However, simply providing education or training is also not an easy solution. Despite many Timorese being sent overseas for study or returning from such, the top heavy civil service may not be able to absorb them at a suitable level, giving them an incentive to return to more developed countries where they are better able to find a job. On the other hand, education and training within an organization is hampered due to the lack of high level training available within East Timor. There is some reluctance to let competent people leave for advanced training or education overseas as they will be lost 'for two or three years...ideally you think that they're the next generation of director generals or beyond' as one official noted.

Attempts continue to provide training and develop the public service. In April 2000 a Civil Service Academy was established, which became the National Institute of Public Administration, coming under Timorese control in 2003. This focused on developing human resource capacity in the civil service, and provides training and various courses, often in combination with partnership of other aid agencies in other countries and international organizations. It continued to lack capacity and expertise into 2010, and seemed to focus on short courses rather than advanced academic study. In 2001 the UN initiated a ten year program entitled Capacity Development for Governance and Public Sector Management, with the aim to prepare for the soon-to-be-independent Timor-Leste and develop a 'lean public administration', but its success remains very mixed (Young Undated). In 2004 The Statue of the Civil Service was promulgated, which sets out in exhaustive detail in 122 articles the rights and duties, employment and disciplinary procedures, amongst other things, of civil servants, including a detailed Code of Ethics. The statute provides for a reasonably standard legal/rational type public service, and a re-affirmation of Weberian type bureaucracy.

\section{The Civil Service Commission}

Of particular note is the establishment of the Civil Service Commission, with commissioners appointed in 2009; three nominated by the government, and two by Parliament, appointed on five year terms. This drew on a predecessor Public Service Commission established under the UN mandate in 2000, with the president of the original commission becoming the first president of the new organization. The earlier commission also has a considerably narrower brief, but also had a focus on developing conditions and legal framework for the civil service. The Commission is notable due to its centralization of appointment of public servants, and its strong focus on its own independence and merit based appointment. Some interviewees claim there was some politicization of the public service and patronage after independence in 2002, and to some extent the establishment of the Commission may be partly to address this. The Commission has wide powers across the public sector and is responsible for ensuring appointment of public servants across the public sector is on merit; sets terms and conditions of employment; promotes a code of ethics; and promotes and provides training, education and staff planning; and provides for disciplinary matter and appeals. In many ways, it resembles the central bodies prevalent in many Westminster regimes before the decentralization reforms of the 1980s and 1990s, with it being 'a bit of a hybrid [a] Portuguese model bolted onto a Commonwealth Australian model and a bit of Timorese as well', according to one advisor. Indeed, the Australian state of Australia was particularly influential, with the 'model we've got is the Victorian model in Australia and the ex-premier of Victoria, Steve Bracks and some of his senior bureaucrats have assisted with the legislation,' as one official noted.

The Commission was unusual in its very broad mandate, and its early and enthusiastic adoption of this mandate may have overwhelmed its capacity, so that UN officials are needed to fill the gaps, as one UN official noted basically [the Commission] is in charge of everything here: recruitment, disciplinary procedures. So it means that all this activity that were initially the responsibility of the ministries have been taken away ....and are now being managed directly since July [2009]. Because it seems that delegation is a bad word here. In the Timorese culture it shows that you are not able to deliver and you want to show that you can do it on your own. ...but in the long-run it cannot continue that way because the Commission is not yet fully staffed ... So that's why we have the UN now supporting the Commission in 
this aspect. Its freedom to act independently will depend to some extent on the personal power of the Commission, although initial indications are positive. As one advisor noted, the Commission provided some clash with the status quo previously [as here] the culture is one where it's the family and friends first. It is [considered] the expected thing and the right thing to do. They [the Commission] take their role serious about being impartial and merit and certainly they've put in the governance structures to hold them accountable...For example they invite and hold regular press conferences. It's not a rubber stamp. They actually discuss very robustly. They have a good mix in the boardroom in terms of skills, but you know, culturally they do try to get the consensus model.

For officials existing in cultures that sees it as normal to patronize family and clan, but who personally subscribe to the norms of a merit based public service, the Commission offers them a useful means of resisting pressure. This role extended even to the President of the Commission. As one official noted We had an example late last year where the President's brother [was] going to be appointed to a position. Of course the advice was given you've got to declare conflict of interests. He got it and he did, and he stood aside. All that was minuted. With the public service generally, the UN's specialist agencies provide support to ministries in capacity development. The various subgroups within the UN work together on various issues, and may even make submissions to Parliament on legislative issues. They play a general role in terms of providing input into the policy process. They have also run courses for students at the two universities. However, capacity and reporting remains low, and planning and strategy is underdeveloped. While 'some of the better ministries' have some planning, develop strategies and report results, basic skills and information remains lacking for some. One of the major roadblocks to reform and in implementing even good intentions continues to be, as one official noted capacity. Each ministry has to do their jobs. The type of reforms, they're fairly simplistic in what they want, but it's the

- capacity of the commission to lead that and deliver it, and

- For the ministries to implement and absorb it [that is the problem].

\section{Conclusion}

Timor Leste faces the classic problems of building an effective state bureaucracy in a fragile state: lack of trained personal and continual problems with building capacity to develop training and education; a ghost workforce of uncertain size; a culture that has not traditionally supported notions of merit based appointment and equality before the law; and the difficulties of dealing with the remnants and questionable loyalties of a post-occupation culture. This is layered upon the stresses and accommodations of 24 years of resistance and occupation. The response so far has been to develop Weberian-type structures under law, with the Commission being a notable example. Despite a great deal of UN and other rhetoric on 'capacity building', and a lot of effort and money, there is still a long way to go, and Timor Leste still relies to an extent on UN, international organization and NGO support for even some basis services. While reform seems to us to be heading in the right direction, there are considerable difficulties in implementing these reforms due to lack of capacity across numerous areas. It might be some time before it Timor can go alone, despite 14 years of dedicated UN and other assistance and the current draw down of the UN mission.

\section{References}

Young, J. (2004). Integrating Civil Service Reform into Sustainable Capacity Development Framework in Timor-Leste. UNDP Project Capacity Development for HRM in the Civil Service. Undated. 